\title{
A knowledge-based view of the Extending Enterprise for enhancing a collaborative innovation advantage
}

\author{
Salma Alguezaui and \\ Euro-Mediterranean Incubator for e-Business \\ Universita' del Salento \\ via per Monteroni s.n., 73100, Lecce (LE), Italy \\ e-mail: s.alguezaui@gmail.com
}

\section{Raffaele Filieri*}

Newcastle Business School

Northumbria University

City Campus East 1, NE1 8ST, Newcastle Upon Tyne, United Kingdom

e-mail: raffaele.filieri@northumbria.ac.uk

*Corresponding author

\begin{abstract}
The Extended Enterprise (EE) framework emerged in high-tech industries with large chains of suppliers to address the current challenges related to innovation and competition in complex scenarios. Since its conceptualization, many transformations have interested the business landscape, such as the emergence of the knowledge economy, the rise of a more open approach to innovation, the outsourcing and offshoring of value creating activities. This paper acknowledges these transformations and attempts to provide an updated model of the EE, termed extending enterprise, based on the knowledge-based view of the firm. The paper is conceptual in nature and research heralding from supply-chain management, operations, strategy, innovation, knowledge management has been brought together in this paper. After more than ten years from its conceptualization, this is the first attempt that discusses the EE framework in light of the knowledge economy.
\end{abstract}

Keywords: Extended Enterprise, Knowledge-based view, Knowledge Transfer, Innovation.

\section{Biographical notes:}

Salma Alguezaui is a PhD candidate at Euro-Mediterranean Incubator for e-Business, Universita' del Salento, Lecce, Italy. Her research interests include supply-chain management, strategic management, offshoring and outsourcing, international business, entrepreneurship and innovation. Her papers have been published among others in Journal of Knowledge Management, Journal of Business Strategy, and book chapters in Cambridge University Press editions and IGI Global publishing.

Dr. Raffaele Filieri is Senior Lecturer in Marketing at Newcastle Business School, Northumbria University, United Kingdom. He received his $\mathrm{PhD}$ in Business Engineering from Universita' Roma 3. His main research interests revolve around business models and architectures, buyer-supplier relations, industrial marketing, online marketing, innovation management. His papers have been accepted for publication in Industrial Marketing Management, Journal of Travel Research, Journal of Knowledge Management, Journal of Business Strategy, and Marketing Intelligence \& Planning. 


\section{Introduction}

Complexity, turbulence, and unpredictability of the business environment have driven the emergence of a new model of the firm, namely the Extended Enterprise (EE). The EE has been defined as "the entire set of collaborating companies both upstream and downstream, from raw materials to end-use consumption, that work together to bring value to the marketplace" (Davis and Spekman, 2004, p.20). The EE organizational model is considered a flexible and adaptive manufacturing system since it represents a more efficient way of designing, producing, and delivering products and services (Browne and Zhang, 1999). The EE promotes a collaborative innovation advantage that derives from the collaboration between manufacturers and suppliers following a win-win approach.

However, different transformations occurring in the business environment, such as among the others the emergence of the knowledge economy, a more open approach to innovation, the adoption of new methods and technologies for knowledge transfer, the outsourcing and offshoring of value creating activities, must be discussed within the EE framework. Considering how the EE framework flexibly adapts to the current changes may foster further research and its adoption from different disciplines. Research so far on the EE has focused on identifying the operational performance measures that can be used to measure its success (Bititci, 2005; Folan and Browne, 2005; Busi and Bititci, 2006); however, these studies focus on the transfer of goods and do not consider the transfer of intangible assets, such as knowledge, which is the most the critical asset in the actual knowledge-based economy (Grant, 1996). This is probably due to the fact that previous conceptualizations of the EE were focused on the optimization of the information transfer processes, failing to discuss the importance of knowledge and of how knowledge is shared for enhancing a collaborative innovation advantage (Jagdev and Thoben, 2010; Busi and Bititci, 2006; Bititci, 2005; Spekman and Davis, 2004; Dyer, 2000; Browne and Zhang, 1999). Though, recent studies have provided evidence of the importance of intensive and durable Knowledge Transfer (KT) patterns between manufacturers and suppliers for improving innovation and 
business performance (Dyer and Nobeoka, 2000; Kotabe, Martin, and Domoto, 2003). The goal of this paper is to redefine the EE from a knowledge-based perspective, focusing on the importance of transferring knowledge (and not only information) in the current economy. The effective transfer of knowledge within the network of partners of the EE can foster the achievement of a collaborative innovation advantage. Case studies from successful extended enterprises have been used in this paper to better delineate the profile of the framework of the knowledge-based EE.

The paper is organized as follows: the next section discusses the foundations of the EE, the subsequent sections discuss the knowledge-based view of the EE in terms of how the EE opens up its innovation processes for fostering the transfer of different knowledge types with suppliers, customers and other partners; while the final paragraph summarizes the main peculiarities of the new organizational model.

\section{The Extended Enterprise}

Whereas the origin of the EE framework can be traced back to the supply-chain management and purchasing literature (Davis and Spekman, 2004); the EE model is adopted by organizations to deal with their customers and suppliers in several industries (Owen et al., 2008; Post et al., 2002). The term EE was coined by Chrysler (Dyer, 2000), to define businesses with an extended supply-chain composed of thousands of suppliers and distributors around the globe. The EE mostly fits high-tech industries, such as aerospace, automotive, pharmaceutical, and semiconductor sectors, which have fostered the development of EE models in recent years. According to Bititci (2005), in the academic literature different terms for indicating similar business structures exist, such as virtual enterprise, extended enterprise, and supply chain, whose differences and boundaries are often ambiguous. These concepts are similar in the sense that they rely on reciprocal trust and dispersion of value creation among actors participating in the supply chain (Lehtinen and Ahola, 2010). However, the EE is different from a supply chain in the respect that in the latter companies 
attempt to maximize their own corporate goals operating in an individualistic manner (Bititci, 2005; Busi and Bititci, 2006). Moreover, in the EE the level of integration and of information exchange is higher than in a supply-chain (Jagdev and Thoben, 2010). This is mainly due to the aim of such a framework, which focuses on creating value to the ensemble of its members. The EE is also different from the virtual enterprise in that in the EE partner members are more stable organizations across the product value chain, entailing a longer term cooperation based on high levels of trust and reciprocity (Browne and Zhang, 1999; Jagdev and Thoben, 2010).

The EE emphasizes that stakeholders' linkages are relational, and not merely transactional (Post et al., 2002). In the antagonistic relationship, suppliers are forced to reduce costs or prices under the threat of losing commitment with the focal firm (Jagdev and Thoben, 2010). From antagonistic relationships between buyers and suppliers, the business relationships in the EE are based on mutually beneficial exchanges and on co-evolution. In the EE, the cost of each transaction is important; however, "value is created in ways that make price considerations secondary and emphasize innovation and knowledge as critical elements in the value equation" (Spekman and Davis, 2004, p.415). The EE instills in the suppliers' network a shared sense of purpose (Kinder, 2003). In fact, in an EE all members (e.g., suppliers, buyers, and manufacturers) are viewed as equally important for the achievement of the objectives of other members and for the sustainability of the system as a whole. This enables a system-wide thinking and a holistic view of network members' activities and goals within the business environment. A win-win strategy is at the basis of the EE orientation in a network of enterprises, which is spread internally between the various departments of the EE, and externally with suppliers and customers. Therefore, differently from the short-term, transaction-cost approach, in which one party's gain comes at the expense of another, the EE focuses on winning together.

The accepted definition of the EE is the one provided by Browne and Zhang in 1999. Such definition identifies three key characteristics of the EE: (a) the manufacturing company 
focuses on the core business, outsourcing non-core business to suppliers and service providers, which enhances competitive capability and mutual dependency, (b) companies form long-term relationships with partners, which are considered as equals, (c) inter-organizational methods, processes and technologies are established to support the activities of the integrated members and to provide them with seamless and effective information exchange (Browne and Zhang, 1999). According to these authors, the EE success is greatly influenced by the speed and efficiency with which information can be exchanged and managed among the different business partners.

However, the EE has to face the new challenges emerging in the knowledge economy, which means a stronger focus on intangible assets such as tacit and explicit knowledge, which strongly contribute to the growth of companies and to their competitive advantage (Kogut and Zander, 1992; Grant, 1996; Nonaka and Takeuchi, 1995; Argote and Ingram, 2000).

Consistently, knowledge and not information is the raw material of innovation, knowledge is critical for achieving competitive advantages in high-technology industries. Knowledge and how knowledge is shared and recombined has been found to be a critical process for innovation generation (Kogut and Zander, 1992; Tsai and Ghoshal, 1998; Martín-de Castro et al., 2011; Martínez-Cañas et al., 2012). Moreover, the formation of external linkages with suppliers provides access to relevant knowledge and offer significant learning opportunities (Mariotti, 2007).

In the light of the growth of knowledge-based firms, the framework of the EE needs to be adapted in order to face the current challenges of the knowledge economy. Accordingly, the main goal of this paper is to re-conceptualize the EE from a knowledgebased perspective, which it is believed to facilitate its diffusion and approach to the industry and other disciplines. The next paragraphs discuss the main characteristics of the knowledge-based view of the extended enterprise. 
The actual economic era has been labeled as knowledge-based economy, since the economic growth in Western economies is directly based on the creation, sharing and application of knowledge and information. The competitive environment evolves rapidly and the capacity to manage knowledge-based intellect is the critical ability in the actual knowledge-based economy (Quinn, 1992). In order to adapt to the changing environment, firms see themselves as learning organizations trying to continuously improve their knowledge capital (Senge, 1990). The knowledge-based view of the firm assumes that the wealth-creating capacity of enterprises is situated on the knowledge and capabilities that they acquire and retain. Knowledge is an intangible asset, and its management is more complex than managing information or any other physical asset such as machineries, raw materials, industrial establishments and the like. Individuals and organizations process, interpret, and integrate new information according to existing knowledge frameworks developed through years of experience. Accordingly, organizations are no longer viewed simply as information processing systems, but rather as learning entities (Dosi and Marengo, 1994).

Although the EE has been defined as a learning organization or knowledge-based organization, existing conceptualizations of the EE have not clearly discussed what knowledge is, and how it differs from information (O’Neill and Sackett, 1994; Bititci, 2005). The foundation of the EE model lies in the resource-based theory and knowledge-based theory of the firm (Alguezaui and Filieri, 2011). The resource-based theory argues that intangible assets that are valuable, rare, imperfectly imitable, and difficult to appropriate, can become a source of competitive advantage (Penrose, 1959; Barney, 1991). Knowledge is one of such intangible assets and presents all these characteristics (Zack, 1999). Further, in the actual conceptualization of the EE, the terms knowledge and information are often used interchangeably (Jagdev and Thoben, 2010); however, knowledge is a different concept from information. Davenport and Prusak $(1998$, p.5) clearly define knowledge as a "fluid mix of framed experiences, values, contextual information, and expert insight that proves a 
framework for evaluating and incorporating new experiences and information”. According to Nonaka and Takeuchi (1995, p. 58-59) "information is a flow of messages, while knowledge is created by that very flow of information, anchored in the beliefs and commitment of its holder...knowledge is essentially related to human action". Knowledge originates and it is applied in the mind of knowers; at organizational level, knowledge is embedded in documents or repositories, in organizational routines, processes, best practices and norms of collaboration. For example, in an extended enterprise in the automotive sector the manufacturer and the suppliers work together to the product prototyping process. In this context, industrial designers within a supplier may possess information about environmental trends and available eco-friendly technologies and materials however the way they assemble the different parts of a product in a way that fit the manufacturer's requirements is entirely dependent on their know-how and know-why, and on how knowledge is shared between the two parties.

\section{Innovating together: opening the innovation process for enhancing knowledge flows}

The current business environment is characterized by the intensification and globalization of competition, the acceleration of technology advancements, the convergence of industries and technologies, and the booming of market niches. The modern EE attempts to adapt to these changes by adopting a more flexible way of producing and supplying products and services, which aims at increasing the pace of innovation with an attempt to timely satisfy customers' needs. Several firms in high technology-based industries need rare and unique knowledge and capabilities to develop new products that match stakeholders' expectations on different aspects such as safety, reduction of pollution, and the like. Increasingly, firms struggle to keep up with the technological and social environment, which change at an unprecedented rate. Such conditions have made the new products development process (NPD) more costly and less profitable than in the past (Chesbrough, 2007). In fact, regardless of the company's size, firms may not have enough skills, knowledge, or resources to effectively exploit the 
potential opportunities of innovation. In order to face these challenges, the knowledge-based EE pursues a collaborative innovation process, which can be best represented by the open innovation model (Chesbrough, 2003, 2007). Such approach to NPD assumes that new products are not only developed in internal $R \& D$ or marketing departments, rather they are increasingly produced outside the firms' boundaries (Chesbrough, 2003, 2007). The open innovation approach suggests involving different actors, such as customers, suppliers, partner firms, universities, strategic alliances, in the innovation process. These cross-geographical and cross-organizational connections aim at sharing, integrating, and deploying new knowledge and capabilities from the business ecosystem in order to create value and to continuously introduce innovations.

Innovation is considered a critical output in buyer-supplier relationships in the EE (Spekman and Davis, 2004). In order to achieve innovation, companies need to enhance their KT processes. Knowledge sharing is defined as the provision or receipt of task information, know-how, and feedback regarding a product or procedure (Hansen, 1999). Lane and Lubatkin (1998) consider the KT process as consisting of evaluation, assimilation, and commercialization of new, external knowledge. The process of KT between the parties is considered a source of innovation and competitive advantage (Kogut and Zander, 1992; Powell et al., 1996; Dyer and Nobeoka, 2000; Argote and Ingram, 2000; McEvily and Marcus, 2005; Berends et. al., 2006). In fact, new knowledge can emerge when individuals and organizations discuss and combine together pieces of existing knowledge (Kogut and Zander, 1992; Nonaka, 1994). Often, even if ideas or suggestions are not original or new, innovation can emerge through a new combination of these ideas and knowledge (Kogut and Zander, 1992). Thus, the integration of capabilities among suppliers and manufacturers may lead to the development of products and services that best fit the needs of markets (Bititci, 2005). For instance, KT influences also the effectiveness of joint problem solving activities among exchange parties (McEvily and Marcus, 2005).

Research has showed that the inclusion of customers and suppliers is beneficial for the 
NPD process (Von Hippel, 2005); industrial marketing and innovation literatures have provided evidence of the innovation potential of ordinary customers and lead-users (Von Hippel, 1988; Thomke and von Hippel, 2002; Von Hippel, 2005; Füller et al., 2011). However, what is new is the easiness and the low costs of customers' involvement initiatives through the adoption of web 2.0 applications. Thanks to social media, different typologies of customers such as creative individuals, brand evangelists, brand passionate and other typologies of customers willing to share their valuable experience and knowledge, can be involved in NPD projects. For instance, the advances in the internet are enabling companies to involve ordinary customers in the NPD process. Accordingly, many car manufacturers (e.g. Fiat, Audi, BMW) are successfully adopting digital technologies to engage customers in the design of new car models and in the development of the features and accessories they would like to find in the new car models. For example, 17 months before the launch of the new Fiat 500, Fiat Auto has created an online co-creation laboratory in which customers were enabled to manage every aspect of the new product launch, from concept product development to the promotion strategy (Filieri and Alguezaui, 2012). Through involving ordinary customer at early stages of the NPD, the company has acquired new knowledge and ideas to develop a product in line with customers' needs on colors, style and accessories (Filieri and Alguezaui, 2012). Moreover, the company has got valuable insights about pricing the car higher than it was planned. Furthermore, suppliers possess a highly specialized knowledge about products and services required to produce high quality products, which has fostered manufacturers to involve suppliers early in the product development process (Clark and Fujimoto, 1991; Lamming, 1993). Early suppliers' involvement into the NPD has proved to produce positive results in terms of productivity, speed, product quality, reduced project costs (Ragatz et al., 1997; Ragatz et al., 2002; Primo and Amundson, 2002; Hagedoorn, 2002; Azadegan, 2011; Cousins et al., 2011). The most popular example is Airbus, which developed innovation solutions for the A380 wings by working closely with its extensive network of suppliers and other partners to develop innovative solutions collaboratively (Owen et al., 2008). Automotive manufacturers, like Fiat Auto, are involving their suppliers early in their 
product prototyping process, outsourcing the design and test of new vehicles. Thanks to synchronized digital manufacturing applications, which enable joint problem solving across a distributed network of suppliers, Fiat Auto is achieving a better integration with $R \& D$ suppliers and a reduction of time-to-market of new vehicles (Fiat Auto, 2011).

Therefore, at the network level, the modern EE identifies, interacts and exploits network value, which has been shown to influence organizational performance and learning (Lampel and Shamsie, 2003; Möller and Svahn, 2006). In the past, the communication with suppliers and other partners was unidirectional. In fact, manufacturers were not used to tap suppliers' knowledge for improving their processes and products. The advances in collaboration and communication technologies enable bidirectional flows of knowledge, ideas, and intangible resources from customers and suppliers.

\section{Knowledge Transfer Technologies}

Information \& Communication Technologies (I\&CTs) are considered a necessary (though not sufficient) condition for an EE to exist (Jagdev and Thoben, 2010), since they enable virtual communication and information sharing between enterprises. The debate on I\&CTs for the EE has been centered on information systems such as EDI, ERP systems, supply-chain management, and customer relationship marketing applications. These systems allow real-time exchange of information throughout the network (Boyson et al., 1999), which is necessary to manage an agile manufacturing system and to rapidly sharing information with suppliers. The EE adopts such systems to enable the trading partners to see the relevant operational transactions of their other supply chain members (Spekman and Davis, 2004). These I\&CTs have improved the flow of information globally from manufacturers to suppliers, warehousing centres, and distributors, enabling to reduce inventory costs, to reduce cycle times, and to rapidly produce and deliver products. However, advances in I\&CTs technologies enable Extended Enterprises not only to communicate and share simple information, rather to collaborate and work 
together in virtual environments. Web 2.0 applications, virtual simulation technologies, and Knowledge Management System (KMS) are facilitating the transfer of both information and knowledge among businesses and between a business and its customers, which increase the level of integration between the different parties. For instance, a KMS is a typology of information system created to support knowledge management processes, namely the processes of knowledge creation, knowledge storage, knowledge retrieval, knowledge transfer, and knowledge application (Alavi and Leidner, 2001; Maier, 2007). KMS extend organization and employees' memory, knowledge, and skills, enabling people to easily access at any time to best practices, problem solutions, and other types of knowledge through knowledge repositories and expert networks (Wu and Wang, 2006). Organizations have created KMS to enable the sharing of the intellectual capital created by knowledge workers in the organization in order to increase decision making effectiveness and ultimately competitive positioning (Rao and Osei-Bryson, 2007). Knowledge repositories and expert maps enable the retrieval and the reuse of complex knowledge within but also between manufacturers and suppliers.

Nowadays, the design and prototyping in many high-tech industries (e.g. automotive, mechanical, and aerospace) are mostly, if not completely, based on virtual simulation technologies (Boland et al., 2007). Example of virtual simulation technologies are computeraided design and computer aided engineering systems (CAD/CAE), which support the design and engineering processes across manufacturers and suppliers. This is leading to significant changes in how product development efforts are organized in these sectors (Vaccaro et al., 2011), which will also impact on the knowledge and capabilities of suppliers in such industries. Increasingly, the technological advancements in the web (e.g. web 2.0 applications, content management systems, web design software) enable rapid and costless bidirectional communications and collaboration. These applications are enabling two-way business-2-business and business-2-customer communications. Accordingly, some companies are gathering knowledge from worldwide internet users by outsourcing different 
activities to them; thus, ordinary customers are directly involved at different stages of the new product development by co-designing, co-inventing, and co-developing new products (Prahalad and Ramaswamy, 2004).

In sum, the advances in I\&CTs enable joint problem solving and collaboration on complex projects. An important condition to enable information sharing through these systems is the technological integration and data visibility across organizations (Owen, 2008). For instance, IBM uses Innovation Jams, which are web-based applications that allow multiple threaded discussions within the company and from several other participating organizations on diverse topics (Owen, 2008). For instance, in the fashion industry the success of global fast fashion retailers such as Zara relies on the capacity to rapidly transfer information and knowledge from stores to design offices, and from design offices to suppliers. Zara managers in the retailing units transmit knowledge and soft information about sales and consumers needs to the designers at headquarters so that they know what customers want or are demanding (Tokatli, 2008). This way the production is adjusted according to customers' needs based on what customers want and how much they want of a product.

\section{Knowledge Types and Sharing Strategies}

The actual conceptualization of the EE equates KT to information transfer; however, the transfer of the two resources is different. In order to share knowledge, manufacturers and suppliers must consider the complexity pertaining to the sharing of both explicit and tacit knowledge. Accordingly, Polanyi (1966) distinguished between two forms of knowledge: tacit and explicit knowledge. On one hand, explicit knowledge refers to a codified form of knowledge that is easy to be transferred in formal and systematic language. This type of knowledge can be acquired through impersonal tools such as documents, ERP systems, groupware, written materials, and libraries. On the other hand, tacit knowledge is evaluated to be hard to codify and thus to transfer since it is "deeply rooted in action, commitment, and involvement in a specific context" (Nonaka, 1994, p.16). Thus, tacit knowledge can be 
considered as added-value facts including one's know-how, expertise and skills applied to a specific situation/context. Tacit knowledge is about work processes, suppliers' ideas and suggestions, latent customers' needs, brand image and the like. Tacit knowledge can be converted into explicit knowledge through different techniques such as observations, learning by doing, employee transfer, focus groups, and brainstorming.

Scholars have developed different approaches for sharing the two types of knowledge; accordingly, Hansen et al. (1999) found that companies may adopt a codification or a personalization strategy. The first refers to the conversion of tacit knowledge into explicit and is based on the transformation of tacit knowledge in the natural language for being archived into database, which are easy to be transmitted to decision agents (Hansen et al., 2005). The first approach is focused on recourse to documents, manuals, knowledge management systems and the like. The second one refers to the interaction between experts for sharing tacit knowledge, which is difficult to codify in the natural language (Hansen et al., 2005). This strategy is based on the development of community of practices, forums, brainstorming sessions, jobs rotation, lessons learnt meetings, and the like. Hansen et al. (1999) suggest companies should focus on one of these approaches for not failing at both, proposing an 80 $20 \%$ split between the dominant and the supporting strategy.

Up to date, the discussion on I\&CTs for the EE has been mainly based on systems that improve the effectiveness of information transmission between manufacturers and suppliers (Dyer, 2000; Spekman and Davis, 2004). However, modern EEs also outsource value creating activities to their suppliers, which imply the sharing of complex and company-specific knowledge (Contractor et al., 2011). Thus, strategies aimed at favoring the sharing of both types of knowledge are being adopted by modern EEs. Accordingly, Toyota developed interactive routines for sharing knowledge with its suppliers (Dyer and Nobeoka, 2000). Routines are patterns of interaction in which Toyota's employees and its suppliers are involved in monthly meetings to discuss production plans, policies, and market trends. These mechanisms have facilitated the sharing of tacit knowledge among Toyota and its suppliers 
(Dyer and Nobeoka, 2000).

\section{Outsourcing and offshoring core capabilities}

In the original definition, Browne and Zhang (1999) state that the EE outsources only noncore businesses to external suppliers. Outsourcing and offshoring models are conceptualized around the premise that the core firm seeks to generate cost advantages and utilize capabilities by working with firms based in less developed countries (Levy, 2005). Offshore business models are 'dynamic' as they denote significant change for the actors over a sustained period (Mason and Leek, 2008).

Today, outsourcing and offshoring are not anymore restricted to the firms' non-core capabilities per se; instead, the outsourcing decisions have been extended to include also what used to be considered core capabilities (Alguezaui and Filieri, 2011). These core capabilities are today distributed to several suppliers. Therefore, companies have started to outsource the manufacturing of the different parts or modules of a product to several suppliers. The manufacturer's main responsibility is often only the assembly of the different components of a final product.

Compared to its past conceptualization, the EE is extending further, crossing also its geographical areas of origin. Hence, companies are also offshoring activities to other countries, and increasingly value creating activities (Contractor et al., 2011). Thus, offshoring and outsourcing is no more concerned only with cost-cutting opportunities but even more important about developing closer connections, creating better services to clients, as well as enhancing creativity and innovation (Contractor et al., 2011). Accordingly, Manning, Massini and Lewin's (2008) survey show that the search for foreign talents has risen to number two ranks, just behind cost savings as a strategic driver for offshoring. Increasingly, outsourcing is aimed at opening up the innovation process to different actors tapping on their talent, knowledge, skills, and capabilities for achieving a collaborative innovation environment.

Evidence of this new approach to outsourcing and offshoring is derived from the world's 
largest wind turbine company Vestas. Vestas company until recently had all its R\&D centres in its country of origin (Denmark), but in the last few years it has now established significant R\&D facilities with a global mandate in Singapore, the U.S., and India (Contractor et al., 2011).

\section{A knowledge-based view of the Extending Enterprise}

The main characteristics of the new organizational model of the EE have been discussed within the previous paragraphs with the support of business examples from different industries (e.g., automotive, aerospace, fashion, wind power solutions). In order to be adopted to study current buyer-supplier relationships, the EE framework has to be reconceptualized in virtue of the new changes that are occurring in the business environment. Accordingly, we suggest using term the Extending Enterprise instead of extended enterprise to denote an enterprise model that does not stop to extend over time and space. The main characteristics of the Extending Enterprise are further summarized below:

a) The manufacturing company outsources and offshores to suppliers and service providers both core and non-core capabilities, which may enhance a global competitive advantage based on the access, integration, and exploitation (KT processes) of external knowledge from different actors, countries, industries, businesses.

b) Advanced I\&CTs, web 2.0 applications and KMS are being adopted by the manufacturing company to enhance collaboration and KT with a broad range of suppliers and actors across the EE with the aim of fostering a collaborative innovation process.

Thus, as shown in the case studies cited above the EE extends beyond its traditional organizational boundaries, by involving external players, such as customers and suppliers in a collaborative activity and in most of the stages of the NPD process. In all these activities, knowledge is often the most important resource that transit across the

EE's and which is used to create a competitive advantage over international 
competitors. A high level of integration is therefore recommended between the EE and its partners. In fact, higher levels of integration or partnerships are required in the supply-chain, especially for complex business conditions (van der Vaart and van Donk, 2008) and the development of complex products and components (Wasti et al., 2006). Moreover, a high level of integration leads to better supplier performance (Kotabe et al., 2003; van der Vaart and van Donk, 2008).

c) The EE forms mutually beneficial and profitable relationships with partners with a longterm horizon and a win-win approach. Longer-term collaborative relationships help to improve the quality of products and to reduce product development lead times (Lamming, 1990). A long-term horizon is in fact fundamental for enabling the development of communication codes, trust, shared languages, and routines, which will facilitate KT between buyers and suppliers (Kogut \& Zander, 1992, 1996; Grant, 1996). A common knowledge (the intersection of individual knowledge assets) is required for the performance of operations and for joint problem solving. Mutual understanding is also important because it affects the organizational members' ability to evaluate, understand, and use the transferred knowledge (Tortoriello and Krackhardt, 2010). Brusoni and Prencipe showed that the amount of common knowledge required for effective knowledge integration is a key issue in aero engines research and other complex production systems (Brusoni and Prencipe, 2001; Brusoni et al., 2001). Inkpen and Pien (2006) reveal that when the novice partner does not possess some amount of prior knowledge that is basic to the disclosed knowledge, it is harder to evaluate and assimilate the disclosed knowledge to enhance exploratory and exploitative innovations. The long term horizon is beneficial to the EE as when the duration of a relationship increases the amount of common experience and knowledge that the supplier and the buyer have also increases, which may result in a better adjustment from both parties. 
Up to now, the discussion on the EE has been dealing with problems of business processes integration and time-cost reduction. The aim of the present paper was to reconceptualize the EE by adopting the knowledge-based view of the firm as a theoretical framework. The new conceptualization integrates different theories and concepts, such as the open innovation approach, KT strategies and technologies. In this vein, research heralding from supply-chain management, operations, strategy, innovation, knowledge management, and general management has been brought together in this paper.

The Extending Enterprise is proposed as a business model that attempts to face global competition through an effective orchestration of a constellation of diverse suppliers with a long term approach, which are involved in value creating activities such the NPD. Knowledge is the most valuable resource that transit across these relationships, as it enables higher performance levels and the development of new products that better satisfies customer needs. Future research is needed to analyze the operations of the Extending Enterprise. In particular, we suggest adopting qualitative methods of investigation, such as ethnographies, case study, and interviews (Braziotis and Tannock, 2011) in order to get an in-depth understanding of how the Extending Enterprise works and on the mechanisms adopted to enhance the processes of knowledge acquisition, integration, and exploitation. Although scholars have been talking about the EE for more than a decade, up to now there are only a few case studies in literature.

In addition, the rising importance of suppliers' networks for enhancing knowledge transfer and achieving collaborative innovations demands a thorough understanding of the most effective mechanisms and strategies to be used to manage and leverage the EE networks. On one hand, relationships are fundamental for attaining the innovation objectives of the EE, as they enable to access to a vast pool of knowledge and other resources, which involves the sharing of risks and benefits in the innovation process. On the other hand, the same relationships may pose some risks since the EE has to deal with a heterogeneous set of suppliers, often located in different countries. These actors may have different and conflicting 
interests and goals; moreover they may have different cultural systems and therefore behavioral norms, increasing the difficulties and risks embedded in sharing both tacit and explicit knowledge.

In this context, the development of social capital is particularly welcome from an Extending Enterprise perspective. In order to counteract the collaboration challenges always present in such networks and to exploit its potential innovation benefits, the Extending Enterprise has to develop some forms of social capital in its network. Social capital's concept includes three dimensions: a structural dimension comprising elements such as network size, centrality, cohesive networks and structural holes, tie strength; a relational dimension comprising elements such as trust, commitment, norms, and shared identity, and a cognitive dimension including elements such as shared representations, narratives, language, and codes and shared values and goals (Nahapiet and Ghoshal, 1998). Scholars could investigate the role that the pattern of business ties (structural dimension), the quality of relationships (relational dimension) and the development of similar cognitive models (cognitive dimension) exercise in the transfer of knowledge, and subsequently how knowledge transfer affects innovation performance in buyer-supplier relationships in the extending enterprise.

Since the EE is responsible for the whole life cycle of a new product, its aim is to orchestrate several suppliers in order to share knowledge and other resources in a mutually beneficial way. To date, the discussion on the EE paradigm has not explored in a systematic way which factors would enhance effective relationships (Braziotis and Tannock, 2011). Scholars have focused their interest on performance measurements based on manufacturing efficiency, delivery time, and costs, considered as necessary to favour wide scale acceptance and practical use of the EE concept by industry and commerce (Folan and Browne, 2005; Bititci, 2005). However, these studies do not consider the importance of collaboration structures and dynamics, which are often the main cause of failure of collaborative initiatives (Busi and Bititci, 2006). In fact, the conceptualization of the EE has not been followed by a framework identifying critical collaboration factors, their interactions, and how they 
contribute to the EE success. All of these factors can be explored through the social capital theory, which has been applied in operations literature to explain buyer performance in terms of operational performance outcomes such as cost, quality, lead time, flexibility, and delivery (Cousins et al., 2006; Krause et al., 2007; Squire et al., 2009; Lawson et al., 2008). The adoption of social capital theory could help scholars to explain how the extending enterprise manages its network of relationships from a structural, relational and cognitive perspective in order to enhance knowledge flows and foster higher performance in the NPD process. 


\section{References}

Alguezaui, S., and Filieri, R. (2011). 'Innovation Across Tech-Firm's Boundaries: a Knowledge-Based View', in Contractor, F., Kumar, V., Pedersen, T., and Kundu, S. (Eds.), Outsourcing and Offshoring of Business Activities: Determinants, Implications and Challenges, (pp. 210-238), Cambridge University Press, Cambridge MA.

Alavi, M. and Leidner, D. (2001). 'Knowledge management and knowledge management systems: Conception foundations and research issues', MIS Quarterly, Vol. 25, No. 1, pp.107-136.

Argote, L. and Ingram, P. (2000). 'Knowledge transfer: A basis for competitive advantage in firms', Organizational Behavior and Human Decision Processes, Vol. 82, No. 1, pp.150169.

Azadegan, A. (2011). 'Benefiting from supplier operational innovativeness: The influence of supplier evaluations and absorptive capacity’, Journal of Supply Chain Management, Vol. 42, No. 2, pp.49-64.

Barney, J. (1991). 'Firm resources and sustained competitive advantage', Journal of Management, Vol. 17, No. 1, pp.99-120.

Berends, H., Van der Bij, H., Debackere, K. and Weggeman, M. (2006). 'Knowledge sharing mechanisms in industrial research', $R \& D$ Management, Vol. 36, No. 1, pp.85-95.

Bititci, U.S. (2005). 'Measuring and managing performance in extended enterprises', International Journal of Operations \& Production Management, Vol. 25 No. 4, pp.333-53.

Boland, R. J., Lyytinen, K. and Yoo, Y. (2007). 'Waves of innovation in project networks: the case of digital 3-D representations in architecture, engineering, and construction', Organization Science, Vol. 18, No. 4, pp.631-47.

Boyson, S., Corsi, M.T., Dresner, E.M. and Harrington, H.L. (1999). Logistics and the Extended Enterprise, Wiley, New York, NY.

Braziotis, C. and Tannock, J. (2011). 'Building the extended enterprise: key collaboration factors', The International Journal of Logistics Management, Vol. 22, No. 3, pp.349-372.

Browne, J., and Zhang, J. (1999). 'Extended and virtual enterprises - similarities and differences', International Journal of Agile Management Systems, Vol.1, No.1, pp.30-36.

Brusoni, S. and Prencipe, A. (2001). 'Exploring the links between product and knowledge dynamics', Journal of Management Studies, Vol. 38, No. 7, pp. 1019-35.

Brusoni, S., Prencipe, A. and Pavitt, K. (2001). 'Knowledge specialization, organizational coupling, and the boundaries of the firm: why do firms know more than they make?', Administrative Science Quarterly, Vol. 46, No. 4, pp. 1185-200. 
Busi, M. \& Bititci, U.S. (2006). 'Collaborative performance management: present gaps and future research', International Journal of Productivity and Performance Management, Vol. 55, No. 1, pp.7-25.

Chesbrough, H. (2003). Open Innovation: The New Imperative for Creating and Profiting from Technology, Harvard Business School Press, MA.

Chesbrough, H. (2007). 'Why firms should have open business models', MIT Sloan Management Review, Vol. 48, No. 2, pp.22-28.

Clark, K.B. and Fujimoto, T. (1991). Product Development Performance: Strategy, Organization, and Management in the World Auto Industry. Harvard Business School Press, Boston

Contractor, F.J., Kumar, V., Kundu, S.K., Pedersen, T. (2011). Global Outsourcing and Offshoring An Integrated Approach to Theory and Corporate Strategy, Cambridge University Press, New York, US.

Cousins, P.D., Handfield, R.B., Lawson, B., and Petersen, K.J. (2006). 'Creating supply chain relational capital: The impact of formal and informal socialization processes', Journal of Operations Management, Vol.24, No.6, pp. 851-863.

Cousins, P.D., Lawson, B., Petersen, K.J. and Handfield, R.B. (2011). 'Breakthrough scanning, supplier knowledge exchange, and new product development performance', Journal of Product Innovation Management, Vol. 28, No. 6, pp.930-942.

Davenport, T.H., and Prusak, L. (1998). Working knowledge: How organizations manage what they know. Massachusetts, Boston, Harvard Business School Press.

Davis E., and Spekman, R. (2004). The Extended Enterprise. Gaining competitive advantage through collaborative supply-chain. Upper Saddle River, NJ, Prentice Hall.

Dyer, J.H. (2000). Collaborative Advantage: Winning through Extended Enterprise Supplier Networks. New York: Oxford University Press.

Dyer, J.H. and Nobeoka, K. (2000). 'Creating and managing a high-performance knowledge sharing network: The Toyota case', Strategic Management Journal, Vol. 21, No. 3, pp.345367.

Filieri, R. and Alguezaui, S. (2012). 'The how and why of customer's cocreation: evidence from the Fiat 500 case study', Proceedings of the Academy of Marketing 2012 Conference, 25 July 2012, Southampton, UK.

Folan, P. and Browne, J. (2005). 'Development of an extended enterprise performance measurement system', Production Planning \& Control, Vol. 16, No. 6, pp. 531-544. 
Füller, J., Hutter, K., Faullant, R. (2011). 'Why co-creation experience matters? Creative experience and its impact on the quantity and quality of creative contributions', $R \& D$ Management, Vol. 41, No. 3, pp.259-273.

Grant, R.M. (1996). 'Toward a knowledge-based theory of the firm', Strategic Management Journal, Vol. 17, Winter Special Issue, pp.109-122.

Hagedoorn, J., and G. Duysters (2002). 'External sources of innovative capabilities: The preference for strategic alliances or mergers and acquisitions', Journal of Management Studies, Vol. 39, No. 2, pp.167-88.

Hansen, M.T. (1999). 'The search-transfer problem: the role of weak ties in sharing knowledge across organizational subunits', Administrative Science Quarterly, Vol. 44, No. 1, pp. 82-111.

Hansen, M.T., Nohria, N., and Tierney, T. (1999). 'What's your strategy for managing knowledge?', Harvard Business Review, Vol. 77, No. 2, pp.106-116.

Hansen, M.T., Mors, M.L., and Lovas, B. (2005). 'Knowledge sharing in organizations: Multiple networks, multiple phases', Academy of Management Journal, Vol. 48, No. 5, pp. 776-793.

Jagdev, H.S. and Thoben, K.-D. (2010). 'Anatomy of enterprise collaborations', International Journal of Production Planning and Control, Vol.12, No.5, pp.437-451.

Kinder, T. (2003). 'Go with the flow-a conceptual framework for supply relations in the era of the extended enterprise', Research Policy, Vol. 32, No. 3, pp.503-523.

Kogut, B. and Zander, U. (1992). 'Knowledge of the firm, combinative capabilities, and the replication of technology', Organization Science, Vol. 3, No. 3, pp.383-397.

Kotabe, M., Martin, Xavier, and Domoto, H. (2003). 'Gaining from vertical partnerships: Knowledge transfer, relationship duration and supplier performance improvement in the U.S. and Japanese automotive industries', Strategic Management Journal, Vol. 24, No. 4, pp. 293-316.

Krause, D.R., Handfield, R.B., and Tyler, B.B. (2007). 'The relationships between supplier development, commitment, social capital accumulation and performance improvement', Journal of Operations Management, Vol. 25, No. 2, pp. 528-545.

Inkpen, A.C., and Pien, W. (2006). 'An examination of collaboration and knowledge transfer: China-Singapore Suzhou Industrial Park', Journal of Management Studies, Vol. 43, No. 4, pp. 779-811.

Lamming, R. (1993). Beyond Partnership: Strategies for Innovation and Lean Supply. Prentice Hall, London. 
Lamming, R. (1990). 'Strategic options for automotive suppliers in the global market', International Journal of Technology Management, Vol. 5, No. 6, pp. 649-684.

Lampel, J. and Shamsie, J. (2003). 'Capabilities in motion: new organizational forms and the reshaping of the Hollywood movie industry', Journal of Management Studies, Vol. 40, No. 8, pp. 2189-210.

Lawson, B., Tyler, B.B., and Cousins, P.D. (2008). 'Antecedents and consequences of social capital on buyer performance improvement', Journal of Operations Management, Vol. 26, No. 3, pp.446-460.

Lehtinen, J. and Ahola, T. (2010). 'Is performance measurement suitable for an extended Enterprise ?', International Journal of Operations \& Production Management, Vol. 30, No. 2, pp.181-204.

Lane, P.J. and Lubatkin, M. (1998). 'Relative absorptive capacity and interorganizational learning', Strategic Management Journal, Vol. 19, No. 5, pp.461-477.

Levy, D. L. (2005). 'Offshoring in the new global political economy', Journal of Management Studies, Vol. 42, No. 3, pp. 685-93.

Maier, R. (2007). Knowledge Management Systems. Information and Communication Technologies for Knowledge Management, $3^{\text {rd }}$ Edition, Berlin: Springer, 2007.

Manning, S., Massini, S. and Lewin, A.Y. (2008). 'A Dynamic Perspective on NextGeneration Offshoring: The Global Sourcing of Science and Engineering Talent', Academy of Management Perspectives, Vol. 22, No. 3, pp. 35-54.

Mariotti, F. (2007). 'Learning to share knowledge in the Italian motorsport industry', Knowledge and Process Management, Vol. 14, No. 2, pp. 81-94.

Martín-de Castro, G., López-Sáez, P. and Delgado-Verde, M. (2011). 'Towards a knowledge-based view of firm innovation. Theory and empirical research', Journal of Knowledge Management, Vol. 15, Issue 6, pp.871-874.

Martínez-Cañas, R., Sáez-Martínez, F.J. and Ruiz-Palomino, P. (2012). 'Knowledge acquisition's mediation of social capital-firm innovation', Journal of Knowledge Management, Vol. 16, Issue 1, pp.61-76.

Mason, K. and Leek, S. (2008). 'Learning to build a supply network: An exploration of dynamic business models', Journal of Management Studies, Vol. 45, No. 4, pp. 759-84.

McEvily, B. and Marcus, A. (2005). 'Embedded ties and the acquisition of competitive capabilities', Strategic Management Journal, Vol. 26, No. 11, pp.1033-55.

Möller, K. and Svahn, S. (2006). 'Role of knowledge in value creation in business nets', Journal of Management Studies, Vol. 43, No. 5, pp. 985-1007. 
Nahapiet, J. and Ghoshal, S. (1998). 'Social capital, intellectual capital, and the organizational advantage', Academy of Management Review, Vol. 23, No.2, pp. 242-266.

Nonaka, I. (1994). 'A dynamic theory of organizational knowledge creation', Organization Science, Vol. 5, No. 1, pp.14-37.

Nonaka, I. and Takeuchi, H. (1995). The Knowledge-Creating Company: How Japanese Companies Create the Dynamics of Innovation, Oxford University Press.

O’Neill, H. and Sackett, P. (1994). 'The Extended Manufacturing Enterprise Paradigm', Management Decision, Vol. 32, No. 8, pp.42-49.

Owen, L., Goldwasser, C., Choate, K. and Blitz, A. (2008). 'Collaborative innovation throughout the extended enterprise', Strategy \& Leadership, Vol. 36, No. 1, pp.39-45.

Penrose, E. (1959). The Theory of the Growth of the Firm, Oxford University Press: Oxford.

Polanyi, M. (1966). The Tacit Dimension, London: Routledge.

Post, J.E., Preston, L.E. and Sachs, S. (2002). 'Managing the extended enterprise: the new stakeholder view', California Management Review, Vol. 45, No. 1, pp.6-28.

Powell, W.W., Koput, K. and Smith-Doerr, L. (1996). 'Interorganizational collaboration and the locus of innovation: networks of learning in biotechnology', Administrative Science Quarterly, Vol. 41, No. 1, pp. 116-45.

Prahalad, C.K. and Ramaswany, V. (2004). 'Co-creation experiences: the next practice in value creation', Journal of Interactive Marketing, Vol. 18, No. 3, pp.5-14.

Primo, M.A.M. and Amundson, S.D. (2002). 'An exploratory study of the effects of supplier relationships on new product development outcomes', Journal of Operations Management, Vol. 20, No. 1, pp.33-52.

Ragatz, G.L., Handfield, R.B. and Scannell, T.V. (1997). 'Success factors for integrating suppliers into new product development', Journal of Product Innovation Management, Vol. 14, No. 3, pp.190-203.

Ragatz, G.L., Handfield, R.B. and Petersen, K.J. (2002). 'Benefits associated with supplier integration into product development under conditions of technology uncertainty', Journal of Business Research, Vol. 55, No. 5, pp.389-400.

Rao, L. And Osei-Bryson, K.-M. (2007). 'Towards defining dimensions of knowledge systems quality’, Expert Systems with Applications, Vol. 33, No. 2, pp. 368-378.

Spekman, R. and Davis, E.W. (2004). 'Risky business: expanding the discussion on risk and the extended enterprise', International Journal of Physical Distribution \& Logistics Management, Vol. 34, No. 5, pp.414-433. 
Squire, B., Cousins, B.D. and Brown, S. (2009). 'Cooperation and knowledge transfer within Buyer-Supplier relationships: The moderating properties of trust, relationship duration and supplier performance', British Journal of Management, Vol. 20, No. 4, pp. 461-477.

Thomke, S., von Hippel, E. (2002). 'Customers as innovators: a new way to create value', Harvard Business Review, Vol. 80, No. 4, pp.74-81.

Tokatli, N. (2008). 'Global sourcing: insights from the global clothing industry. The case of Zara, a fast fashion retailer', Journal of Economic Geography, Vol. 8, No. 1, pp. 21-38.

Tortoriello, M. and Krackhardt, D. (2010). 'Activating cross-boundary knowledge: Simmelian ties and the generation of innovation', Academy of Management Journal, Vol. 53, No. 1, pp. 167-181.

Tsai, W., Ghoshal, S. (1998). 'Social capital and value: the role of intrafirm networks', Academy of Management Journal, Vol. 41, No. 4, pp.464-76.

Vaccaro, A., Brusoni, S., Veloso, F. (2011). 'Virtual Design, Problem Framing, and Innovation: An Empirical Study in the Automotive Industry', Journal of Management Studies, Vol.48, No.1, pp.99-122.

Van der Vaart, T. and van Donk, D.P. (2008). 'A critical review of survey-based research in supply chain integration', International Journal of Production Economics, Vol. 111, No.1, pp. 42-55.

Von Hippel, E. (1988). The Sources of Innovation, Oxford University Press, New York: NY.

Von Hippel, E. (2005). Democratizing innovation, The MIT Press, Cambridge, US.

Wasti, S.N., Kozan, M.K. and Kuman, A. (2006). Buyer-supplier relationships in the Turkish automotive industry. International Journal of Operations and Production Management, Vol. 26 No. 9, pp. 947-970.

Wu, J.-H. and Wang, Y.-M. (2006). 'Measuring KMS success: a respecification of the DeLone and McLean's model', Information \& Management, Vol. 43, No. 6, pp.728-739.

Zack, M. (1999). 'Developing a knowledge strategy', California Management Review, Vol. 41, No. 3, pp.125-145. 